Supporting Information

\title{
Co-exposure degradation of purine derivatives in sulfate radical-mediated oxidation process
}

\begin{abstract}
Shuangshuang Cheng ${ }^{1}$, Yu Lei ${ }^{1}$, Xin Lei ${ }^{1}$, Yanheng Pan ${ }^{1}$, Yunho Lee ${ }^{2}$, Xin Yang,**
\end{abstract}
${ }^{1}$ School of Environmental Science and Engineering, Guangdong Provincial Key Laboratory of Environmental Pollution Control and Remediation Technology, Sun Yat-sen University, Guangzhou 510275, China

${ }^{2}$ School of Earth Sciences and Environmental Engineering, Gwangju Institute of Science and Technology (GIST), Gwangju 61005, Republic of Korea

* Corresponding author, Tel: +86-2039332690, email: yangx36@mail.sysu.edu.cn 22 Pages, 3 Texts, 5 Tables, 12 Figures 


\section{$\underline{\text { List of contents }}$}

\section{Texts:}

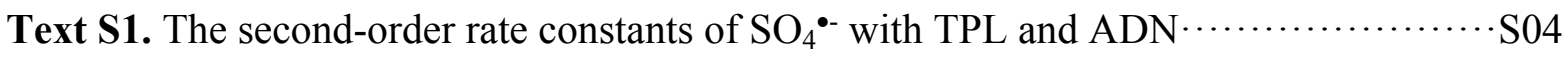

Text S2. The second-order rate constants of TPL and ADN(-H) ${ }^{\bullet} \ldots \ldots \ldots \ldots \ldots \ldots \ldots \ldots, \mathrm{S} 05$

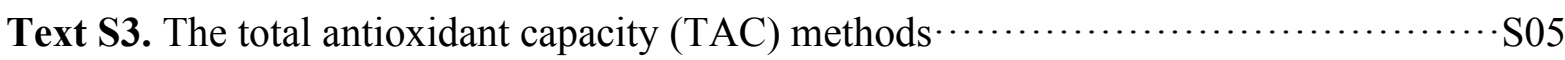

Tables:

Table S1. The structures and properties of TPL and

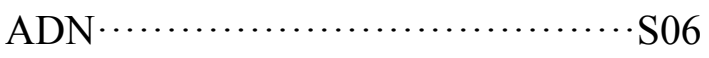

Table S2. Modeled steady-state concentrations of $\mathrm{HO}^{\bullet}$ and $\mathrm{SO}_{4}{ }^{\bullet-}$ during UV/PDS treatment in single-component system (3.0 $\mu \mathrm{M}$ TPL or $3.0 \mu \mathrm{M} \mathrm{ADN})$ and mixture systems $\cdots \cdots \cdots \cdot$. 07

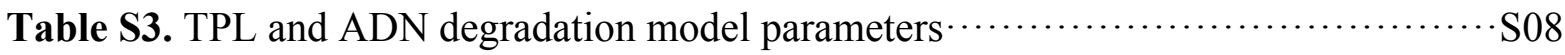

Table S4. The structures and properties of selected purines, pyrimidines and phenols $\cdots \cdots$ S09

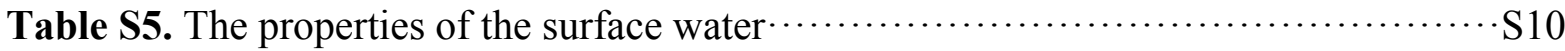

\section{Figures:}

Figure S1. Degradation of (a) TPL and (b) ADN under UV irradiation and in PDS treatment alone in single-component system and in mixture systems at $\mathrm{pH} 7.0 \cdots \cdots \cdots \cdots \cdots \cdots \cdots \cdot \mathrm{S} 11$

Figure S2. The degradation of TPL and ADN during UV/PDS treatment in single-component system $(3.0 \mu \mathrm{M}$ TPL or $3.0 \mu \mathrm{M} \mathrm{ADN})$ and mixture systems $\cdots \ldots \ldots \ldots \ldots \ldots \ldots \ldots \ldots \ldots+\mathrm{S} 11$

Figure S3. (a) Transient decay traces of $\mathrm{SO}_{4}{ }^{\circ-}$ at $450 \mathrm{~nm}$ with different concentrations of TPL. (b) First-order decay rate constant $k_{\text {obs }}$ Vs. [TPL] $\mathrm{S} 12$

Figure S4. (a) Transient decay traces of $\mathrm{SO}_{4}{ }^{\bullet-}$ at $450 \mathrm{~nm}$ with different concentrations of ADN. (b) First-order decay rate constant $k_{\text {obs }}$ vs. [ADN]

Figure S5. The degradation of (a) ADN and (b) TPL during UV/PDS treatment in 
Figure S6. The predicted TPL degradation rate constant $k_{\mathrm{ADN}(-\mathrm{H}) \bullet, T P L}^{\prime}$ during UV/PDS treatment at various ADN concentrations

Figure S7. The predicted ADN degradation rate constant $k_{\mathrm{TPL}, \mathrm{ADN}}^{\prime}$ during UV/PDS treatment at various TPL concentrations S14

Figure S8. (a)The degradation of TPL and ADN in mixture system $(3.0 \mu \mathrm{M}$ TPL and $3.0 \mu \mathrm{M}$ $\mathrm{ADN})$ and $(\mathrm{b})$ the degradation of $\mathrm{ADN}$ in mixture system $(0.1 \mu \mathrm{M}$ TPL and $3.0 \mu \mathrm{M}$ ADN) without $\mathrm{N}_{2}$ purging (solid line) and with $\mathrm{N}_{2}$ purging (dash line) during UV/PDS treatment S15

Figure S9. The degradation of $3.0 \mu \mathrm{M}$ ADN during UV/PDS treatment in mixtures containing $3.0 \mu \mathrm{M}$ (a) phenols, (b) purines with low reduction potential ( $<1.32 \mathrm{~V}$ vs SHE), (c) purines with high redox potential $(>1.32 \mathrm{~V}$ vs SHE), (d) pyrimidines

Figure S10. First-order decay rate constants of $\mathrm{ADN}(-\mathrm{H})^{\bullet}$ at various concentrations of (a) xanthine; (b) uric acid; (c) catechol S17

Figure S11. The degradation of TPL and ADN during UV/PDS treatment in single-component system and in mixture systems in (a) a simulated natural water containing Suwannee River NOM isolate (Cat. No. 2R101N, International Humic Substances Society) $2.5 \mathrm{mgC} \mathrm{L}^{-1}$ as DOC; (b) a real surface water S19

Figure S12. The total antioxidant capacity of NOM in the absence and presence of pollutants after 10 min during UV/PDS treatment. S20 


\section{Text S1. The second-order rate constants of $\mathrm{SO}_{4}{ }^{--}$with TPL and ADN}

The rate constants of TPL and $\mathrm{ADN}$ with $\mathrm{SO}_{4}{ }^{--}$were determined using laser flash photolysis. A LKS80 laser flash photolysis system (Applied Photophysics Ltd., UK) was employed using the fourth harmonic mode of a Nd:YAG laser $(266 \mathrm{~nm})$. A xenon lamp $(150 \mathrm{~W})$ was used as a detecting light source. The output from a pulsed laser was directed onto a sample cuvette at right angles to a probe light. The variations in the optical signal were recorded using a Philips PM3323B digital oscilloscope and fed to a computer. Fresh samples were prepared before each experiment and bubbled with high-purity $\mathrm{N}_{2}$ for 20 min to remove dissolved oxygen. The solution $\mathrm{pH}$ was adjusted to $7.0 \pm 0.3$ with $\mathrm{NaOH}$.

$\mathrm{SO}_{4}{ }^{\bullet-}$ was generated by $266 \mathrm{~nm}$ photolysis of $25 \mathrm{mM}$ peroxydisulfate (eq. S1). The transient absorption of $\mathrm{SO}_{4}{ }^{\bullet-}$ was featured at $450 \mathrm{~nm}$ and $330 \mathrm{~nm}$ (Figure 3a). The first-order decay rate constant at $450 \mathrm{~nm}$ was monitored at various TPL concentrations, as shown in Figure S3. The slope of the decay rate constant versus TPL concentration curve was linear.

$$
\begin{aligned}
& \mathrm{S}_{2} \mathrm{O}_{8}{ }^{2-}+h v \rightarrow 2 \mathrm{SO}_{4}{ }^{\bullet-} \\
& k_{\mathrm{obs}}=k[\mathrm{TPL}]+\mathrm{G}
\end{aligned}
$$

Where $k$ represents the second-order rate constant of TPL reacting with $\mathrm{SO}_{4}{ }^{\bullet-}$, [TPL] is the concentration of TPL and $\mathrm{G}$ is the y-intercept that represents losses of $\mathrm{SO}_{4}{ }^{\bullet-}$ due to other reactions (e.g., quenching by $\mathrm{H}_{2} \mathrm{O}$ and reacting with the precursor $\mathrm{S}_{2} \mathrm{O}_{8}{ }^{2-}$ ). The second-order rate constant of $\mathrm{SO}_{4}{ }^{--}$with TPL was calculated to be $(2.95 \pm 0.29) \times 10^{9} \mathrm{M}^{-1} \mathrm{~s}^{-1}$ at $\mathrm{pH} 7.0$.

The rate constant of $\mathrm{SO}_{4}{ }^{-}$with $\mathrm{ADN}$ was determined similarly. The second-order rate constant for that reaction was determined as $(1.90 \pm 0.24) \times 10^{9} \mathrm{M}^{-1} \mathrm{~s}^{-1}$ (Figure S4). The second-order rate constants for the reactions of $\mathrm{SO}_{4}{ }^{--}$with xanthine, catechol and uric acid was also similarly determined. The results were shown in Table S4. 


\section{Text S2. The second-order rate constants of TPL and ADN(-H)•}

The second-order rate constant of TPL and ADN(-H) ${ }^{\bullet}$ was determined using the same laser flash photolysis system. A solution containing $250 \mathrm{mM}$ peroxydisulfate and $0.24 \mathrm{mM}$ $\mathrm{ADN}$ was irradiated. The spectra at $340 \mathrm{~nm}$ and in the broad band from 510 to $610 \mathrm{~nm}$ were both attributed to $\mathrm{ADN}(-\mathrm{H})^{\bullet}$ generated from the reaction of $\mathrm{ADN}$ with $\mathrm{SO}_{4}{ }^{\bullet-}$ (Figure $3 \mathrm{c}$ ). The changes in the kinetic trace at $590 \mathrm{~nm}$ were tracked to reflect the decay of $\operatorname{ADN}(-\mathrm{H})^{\bullet}$, as neither $\mathrm{SO}_{4}{ }^{\bullet-}$ nor TPL ${ }^{\bullet}$ showed significant absorption at $590 \mathrm{~nm}$ (Figures $3 \mathrm{a}$ and $3 \mathrm{~b}$ ). The absorption attributable to $\mathrm{ADN}(-\mathrm{H})^{\bullet}$ decreased with the addition of TPL. The decay rate $k_{\mathrm{obs}}$ of the $\operatorname{ADN}(-\mathrm{H})^{\bullet}$ signal increased with increasing TPL concentration (Figure 3d). By plotting the observed decay rates of $\mathrm{ADN}(-\mathrm{H})^{\bullet}$ versus $\mathrm{TPL}$ concentration, the second-order reaction rate constant of $\mathrm{ADN}(-\mathrm{H})^{\bullet}$ with TPL was determined to be $(1.94 \pm 0.18) \times 10^{8} \mathrm{M}^{-1} \mathrm{~s}^{-1}$.

$$
\mathrm{ADN}(-\mathrm{H})^{\bullet}+\mathrm{TPL}+\mathrm{H}_{2} \mathrm{O} \rightarrow \mathrm{ADN}+\mathrm{TPL}^{\bullet+}+\mathrm{HO}^{-} \quad \mathrm{k}=(1.94 \pm 0.18) \times 10^{8} \mathrm{M}^{-1} \mathrm{~s}^{-1}
$$

The approach to determine the second-order rate constants of $\mathrm{ADN}(-\mathrm{H})^{\bullet}$ with xanthine, catechol and uric acid was similar. The results were shown in Figure S10 and Figure 4.

\section{Text S3. The total antioxidant capacity (TAC) methods}

As phenolic contents in NOM were related with the redox reactions with ADN/TPL, the changes of TAC of NOM, were mainly contributed by total phenolics. The TAC was quantified using a Folin-Ciocalteu (F-C) assay. The F-C assay relies on the transfer of electrons from a substrate to phosphomolybdic/phosphotungstic acid complexes in alkaline medium to form blue complexes, which can be quantified spectroscopically at $760 \mathrm{~nm} .^{1,2}$ Briefly, $0.5 \mathrm{~mL}$ Folin-Ciocalteu reagent was added to a $10 \mathrm{~mL}$ sample and the mixture was incubated at room temperature for $5 \mathrm{~min}$. Then, add $1.5 \mathrm{~mL}$ of $20 \%(\mathrm{w} / \mathrm{v})$ aqueous $\mathrm{Na}_{2} \mathrm{CO}_{3}$ into the tube and incubate at $25^{\circ} \mathrm{C}$. After 2 hours, the absorbance was determined at $760 \mathrm{~nm}$ and compared with a blank-corrected calibration curve. The antioxidant capacity was calculated by using gallic acid as a standard, that is gallic acid equivalents $\left(\mathrm{mg} \mathrm{L}^{-1}\right){ }^{3}$ 
Table S1. The structures and properties of TPL and ADN.

\begin{tabular}{|c|c|c|}
\hline Purines & Adenine (ADN) & Theophylline (TPL) \\
\hline Structure & & \\
\hline Molecular formula & $\mathrm{C}_{5} \mathrm{H}_{5} \mathrm{~N}_{5}$ & $\mathrm{C}_{7} \mathrm{H}_{8} \mathrm{~N}_{4} \mathrm{O}_{2}$ \\
\hline Molecular weight & 135.05 & 180.06 \\
\hline $\mathrm{pKa}$ & $4.3,9.8^{4}$ & $3.3,9.8^{5}$ \\
\hline $\mathrm{E}_{7}^{0}(\mathrm{~V})$ vs SHE & $1.32^{6}$ & $1.24^{7}$ \\
\hline $\mathrm{k}_{\mathrm{HO}} \cdot\left(10^{9} \mathrm{M}^{-1} \mathrm{~s}^{-1}\right)$ & $5.8^{8}$ & $6.3^{8}$ \\
\hline $\mathrm{k}_{\mathrm{SO} 4 \cdot-}\left(10^{9} \mathrm{M}^{-1} \mathrm{~s}^{-1}\right)$ & $1.90 \pm 0.24^{a}$ & $2.95 \pm 0.29^{a}$ \\
\hline
\end{tabular}

${ }^{a}$ Measured in this study. 
Table S2. Modeled steady-state concentrations of $\mathrm{HO}^{\bullet}$ and $\mathrm{SO}_{4}{ }^{\bullet-}$ during UV/PDS treatment in single-component system $(3.0 \mu \mathrm{M}$ TPL or $3.0 \mu \mathrm{M}$ ADN $)$ and mixture systems.

\begin{tabular}{|c|c|c|}
\hline & $\begin{array}{c}{\left[\mathrm{HO}^{\bullet}\right]_{\mathrm{ss}}} \\
\left(\times 10^{-14} \mathrm{M}\right)\end{array}$ & $\begin{array}{c}{\left[\mathrm{SO}_{4}^{\bullet-}\right]_{\mathrm{ss}}} \\
\left(\times 10^{-13} \mathrm{M}\right)\end{array}$ \\
\hline $3.0 \mu \mathrm{M} \mathrm{ADN}$ & 3.09 & 10.12 \\
\hline $3.0 \mu \mathrm{M}$ TPL & 2.32 & 8.13 \\
\hline $3.0 \mu \mathrm{M}$ ADN $+3.0 \mu \mathrm{M}$ TPL & 0.66 & 4.04 \\
\hline $3.0 \mu \mathrm{M}$ ADN $+0.1 \mu \mathrm{M}$ TPL & 2.86 & 9.66 \\
\hline $3.0 \mu \mathrm{M}$ ADN $+0.3 \mu \mathrm{M}$ TPL & 2.48 & 8.85 \\
\hline $3.0 \mu \mathrm{M}$ ADN $+0.5 \mu \mathrm{M}$ TPL & 2.18 & 8.16 \\
\hline $3.0 \mu \mathrm{M}$ ADN $+0.75 \mu \mathrm{M}$ TPL & 1.86 & 7.43 \\
\hline $3.0 \mu \mathrm{M}$ ADN $+1.0 \mu \mathrm{M}$ TPL & 1.61 & 6.82 \\
\hline $3.0 \mu \mathrm{M}$ ADN $+1.5 \mu \mathrm{M}$ TPL & 1.24 & 5.84 \\
\hline $3.0 \mu \mathrm{M}$ ADN $+6.0 \mu \mathrm{M}$ TPL & 0.27 & 2.43 \\
\hline $3.0 \mu \mathrm{M}$ TPL $+0.5 \mu \mathrm{M}$ ADN & 1.76 & 6.93 \\
\hline $3.0 \mu \mathrm{M}$ TPL $+1.5 \mu \mathrm{M}$ ADN & 1.12 & 5.39 \\
\hline $3.0 \mu \mathrm{M}$ TPL $+6.0 \mu \mathrm{M}$ ADN & 0.30 & 2.62 \\
\hline $3.0 \mu \mathrm{M}$ TPL $+9.0 \mu \mathrm{M}$ ADN & 0.17 & 1.87 \\
\hline $3.0 \mu \mathrm{M}$ TPL $+12 \mu \mathrm{M}$ ADN & 0.10 & 1.42 \\
\hline $3.0 \mu \mathrm{M}$ TPL $+15 \mu \mathrm{M}$ ADN & 0.07 & 1.12 \\
\hline
\end{tabular}


Table S3. TPL and ADN degradation model parameters

\begin{tabular}{|c|c|}
\hline Parameter (units) & Value \\
\hline$\Phi_{\mathrm{SO} 4 \bullet-}$ & 0.7 mol Einstein ${ }^{-1} 9$ \\
\hline $\mathrm{I}_{0}$ & $1.65 \times 10^{-7}$ Einsteins $\mathrm{L}^{-1} \mathrm{~s}^{-1}$ \\
\hline $\mathrm{k}_{\mathrm{SO} 4 \bullet-, \mathrm{HO}-}$ & $7.0 \times 10^{7} \mathrm{M}^{-1} \mathrm{~s}^{-19}$ \\
\hline $\mathrm{k}_{\mathrm{SO} 4 \bullet-, \mathrm{H} 2 \mathrm{O}}$ & $600 \mathrm{~s}^{-19}$ \\
\hline $\mathrm{k}_{\mathrm{SO} 4 \bullet-, \mathrm{TPL}}$ & $(2.95 \pm 0.29) \times 10^{9} \mathrm{M}^{-1} \mathrm{~s}^{-1 a}$ \\
\hline $\mathrm{k}_{\mathrm{SO} 4 \bullet-, \mathrm{ADN}}$ & $(1.90 \pm 0.24) \times 10^{9} \mathrm{M}^{-1} \mathrm{~s}^{-1 a}$ \\
\hline $\mathrm{k}_{\mathrm{SO} 4 \bullet-, \mathrm{PDS}}$ & $6.5 \times 10^{5} \mathrm{M}^{-1} \mathrm{~s}^{-19}$ \\
\hline $\mathrm{k}_{\mathrm{HO} \cdot \mathrm{TPL}}$ & $6.3 \times 10^{9} \mathrm{M}^{-1} \mathrm{~s}^{-18}$ \\
\hline $\mathrm{k}_{\mathrm{HO} \bullet \mathrm{ADN}}$ & $5.8 \times 10^{9} \mathrm{M}^{-1} \mathrm{~s}^{-18}$ \\
\hline $\mathrm{k}_{\mathrm{HO} \bullet, \mathrm{PDS}}$ & $1.4 \times 10^{7} \mathrm{M}^{-1} \mathrm{~s}^{-19}$ \\
\hline $\mathrm{k}_{\mathrm{ADN}(-\mathrm{H}) \bullet, \text { rxn }}$ & $8.4 \mathrm{~s}^{-1 b}$ \\
\hline
\end{tabular}

${ }^{a}$ Measured in this study. ${ }^{b}$ Estimated by global model fit. 
Table S4. The structures and properties of selected purines, pyrimidines and phenols

\begin{tabular}{|c|c|c|c|c|c|}
\hline & Structure & $\begin{array}{l}\text { Molecular } \\
\text { formula }\end{array}$ & $\begin{array}{l}\mathrm{E}^{0}(\mathrm{~V}) \mathrm{vs} \\
\mathrm{SHE} \text { at } \mathrm{pH} \\
7.0\end{array}$ & $\begin{array}{l}\mathrm{k}_{\mathrm{HO}}\left(10^{9}\right. \\
\left.\mathrm{M}^{-1} \mathrm{~s}^{-1}\right)\end{array}$ & $\begin{array}{l}\mathrm{k}_{\mathrm{SO} 4 \cdot-}\left(10^{9}\right. \\
\left.\mathrm{M}^{-1} \mathrm{~s}^{-1}\right)\end{array}$ \\
\hline \multicolumn{6}{|l|}{ Purines } \\
\hline theobromine & & $\mathrm{C}_{7} \mathrm{H}_{8} \mathrm{~N}_{4} \mathrm{O}_{2}$ & $1.54^{7}$ & $5.8^{8}$ & - \\
\hline caffeine & & $\mathrm{C}_{8} \mathrm{H}_{10} \mathrm{~N}_{4} \mathrm{O}_{2}$ & $1.60^{7}$ & $6.9^{8}$ & $4.5^{10}$ \\
\hline adenosine & & $\mathrm{C}_{10} \mathrm{H}_{13} \mathrm{~N}_{5} \mathrm{O}_{4}$ & $1.42^{11}$ & $4.2^{8}$ & $2.7^{8}$ \\
\hline guanine & & $\mathrm{C}_{5} \mathrm{H}_{5} \mathrm{~N}_{5} \mathrm{O}$ & $1.04^{6}$ & - & - \\
\hline \multirow[t]{2}{*}{ xanthine } & & $\mathrm{C}_{5} \mathrm{H}_{4} \mathrm{~N}_{4} \mathrm{O}_{2}$ & $0.93^{6}$ & $5.2^{8}$ & $0.132 \pm$ \\
\hline & & & & & $0.02^{a}$ \\
\hline \multirow[t]{2}{*}{ uric acid } & & $\mathrm{C}_{5} \mathrm{H}_{4} \mathrm{~N}_{4} \mathrm{O}_{3}$ & $0.54^{12}$ & $7.2^{8}$ & $0.059 \pm$ \\
\hline & & & & & $0.003^{a}$ \\
\hline hypoxanthine & & $\mathrm{C}_{5} \mathrm{H}_{4} \mathrm{~N}_{4} \mathrm{O}$ & $1.30^{12}$ & $6.5^{8}$ & - \\
\hline \multicolumn{6}{|l|}{ Pyrimidines } \\
\hline uracil & & $\mathrm{C}_{4} \mathrm{H}_{4} \mathrm{~N}_{2} \mathrm{O}_{2}$ & $1.34^{6}$ & $4.8^{8}$ & $3^{8}$ \\
\hline cytosine & & $\mathrm{C}_{4} \mathrm{H}_{5} \mathrm{~N}_{3} \mathrm{O}$ & $1.44^{6}$ & $6.8^{8}$ & - \\
\hline \multicolumn{6}{|l|}{ Phenols } \\
\hline phenol & & $\mathrm{C}_{6} \mathrm{H}_{6} \mathrm{O}$ & $0.87^{13 b}$ & $6.6^{8}$ & $8.8^{8}$ \\
\hline
\end{tabular}


4-methoxyyphenol<smiles>COc1ccc(O)cc1</smiles>

4-nitrocatechol<smiles>O=C(O)c1ccc(O)c(I)c1</smiles>

catechol<smiles>Oc1ccccc1O</smiles>

4-methylcatechol<smiles>Cc1ccc(O)c(O)c1</smiles>

$\mathrm{C}_{7} \mathrm{H}_{8} \mathrm{O}_{2}$

$0.43^{14}$

4-aminophenol<smiles>Nc1ccc(O)cc1</smiles>

$\mathrm{C}_{7} \mathrm{H}_{8} \mathrm{O}_{2}$

$0.65^{13 b}$

$26^{8}$

$\mathrm{C}_{6} \mathrm{H}_{5} \mathrm{NO}_{4} \quad 0.64{ }^{14}$

$\mathrm{C}_{6} \mathrm{H}_{6} \mathrm{O}_{2}$

$0.47^{14}$

$11^{8}$

$2.04 \pm$

$0.13^{a}$

Note: - denotes not available. ${ }^{a}$ Measured in this study. ${ }^{\mathrm{b}}$ At $\mathrm{pH}$ 5.6.

Table S5. The properties of the surface water

\begin{tabular}{ll}
\hline parameter & value \\
\hline $\mathrm{pH}$ & 7.40 \\
$\mathrm{TOC}(\mathrm{mgC} / \mathrm{L})$ & 1.74 \\
$\mathrm{NH}_{3}-\mathrm{N}(\mathrm{mg} / \mathrm{L})$ & 0.017 \\
$\mathrm{Br}^{-}(\mathrm{mg} / \mathrm{L})$ & 0.035 \\
$\mathrm{Cl}^{-}(\mathrm{mg} / \mathrm{L})$ & 6.36 \\
$\mathrm{SO}_{4}{ }^{2-}(\mathrm{mg} / \mathrm{L})$ & 18.30 \\
$\mathrm{HCO}_{3}{ }^{-}(\mathrm{mgC} / \mathrm{L})$ & 20.68 \\
\hline
\end{tabular}



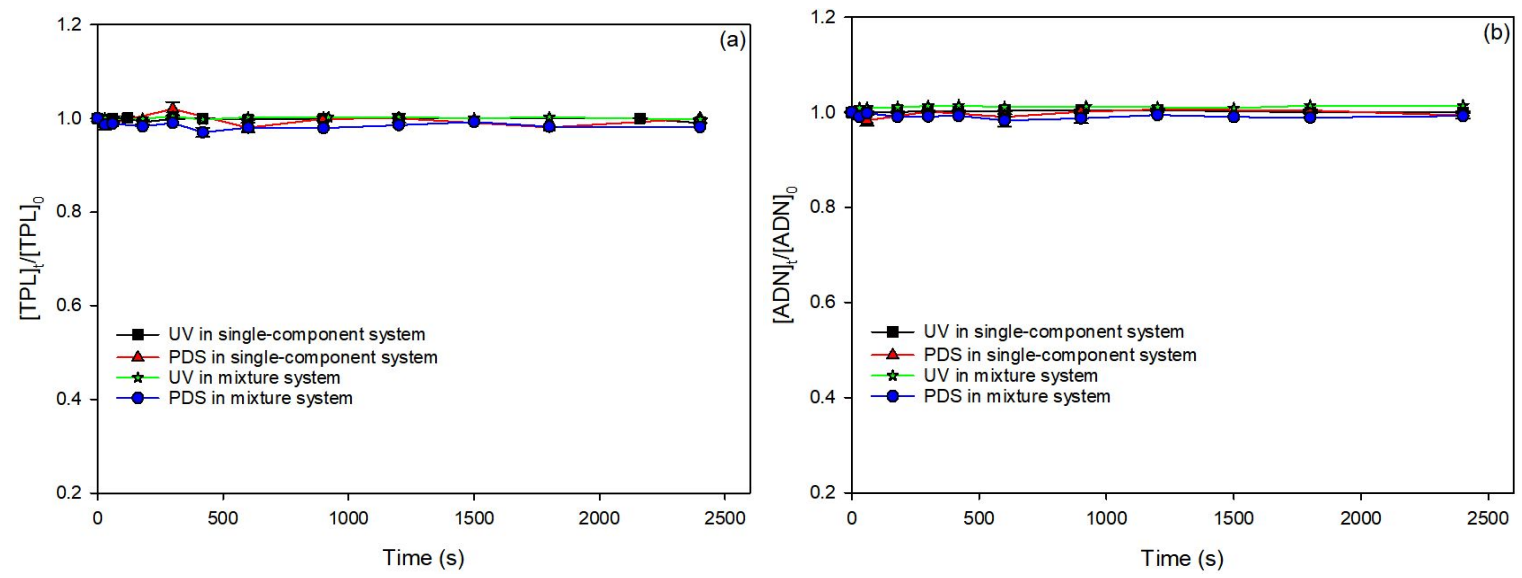

Figure S1. Degradation of (a) TPL and (b) ADN under UV irradiation and in PDS treatment alone in single-component system and in mixture systems at $\mathrm{pH}$ 7.0. Conditions: $\mathrm{I}_{0}=0.16$ $\mathrm{mW} / \mathrm{cm}^{2},\left[\mathrm{~K}_{2} \mathrm{~S}_{2} \mathrm{O}_{8}\right]=290 \mu \mathrm{M}$.

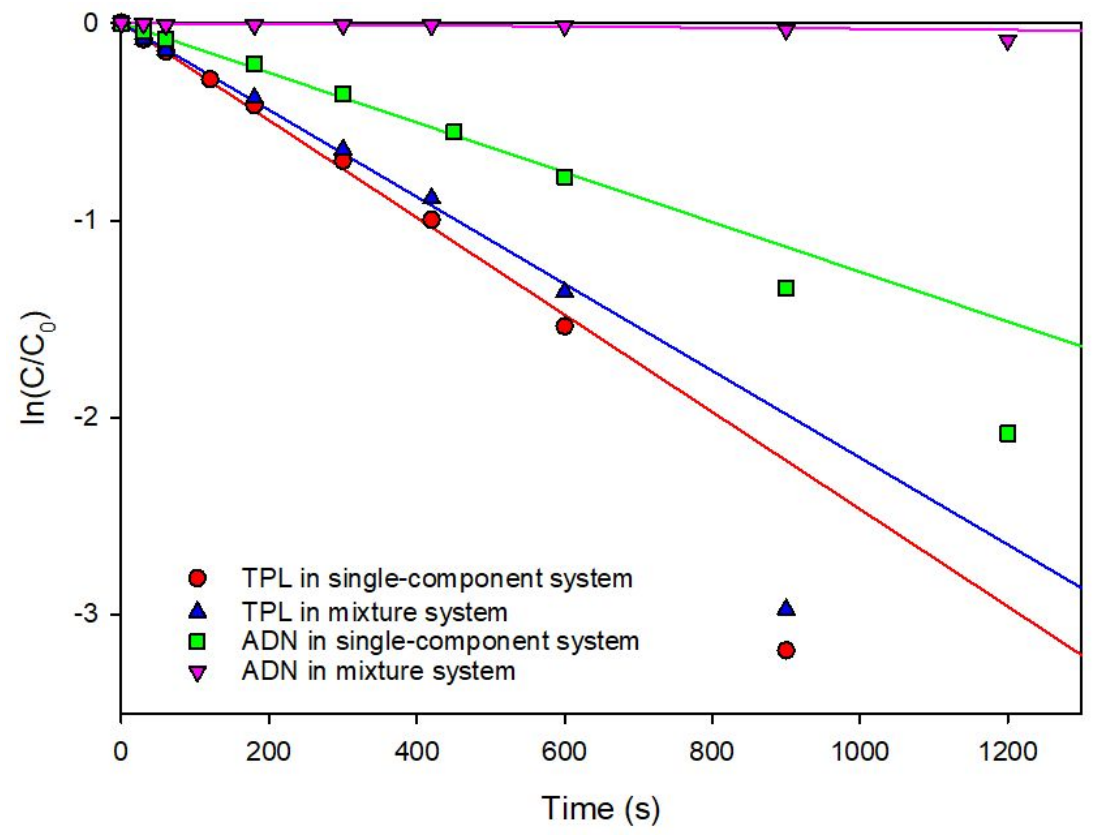

Figure S2. The degradation of TPL and ADN during UV/PDS treatment in single-component system $\left(3.0 \mu \mathrm{M}\right.$ TPL or $3.0 \mu \mathrm{M}$ ADN) and mixture systems. Conditions: $\mathrm{I}_{0}=0.16 \mathrm{~mW} / \mathrm{cm}^{2}$, $\mathrm{pH}=7.0,\left[\mathrm{~K}_{2} \mathrm{~S}_{2} \mathrm{O}_{8}\right]=290 \mu \mathrm{M}$. 

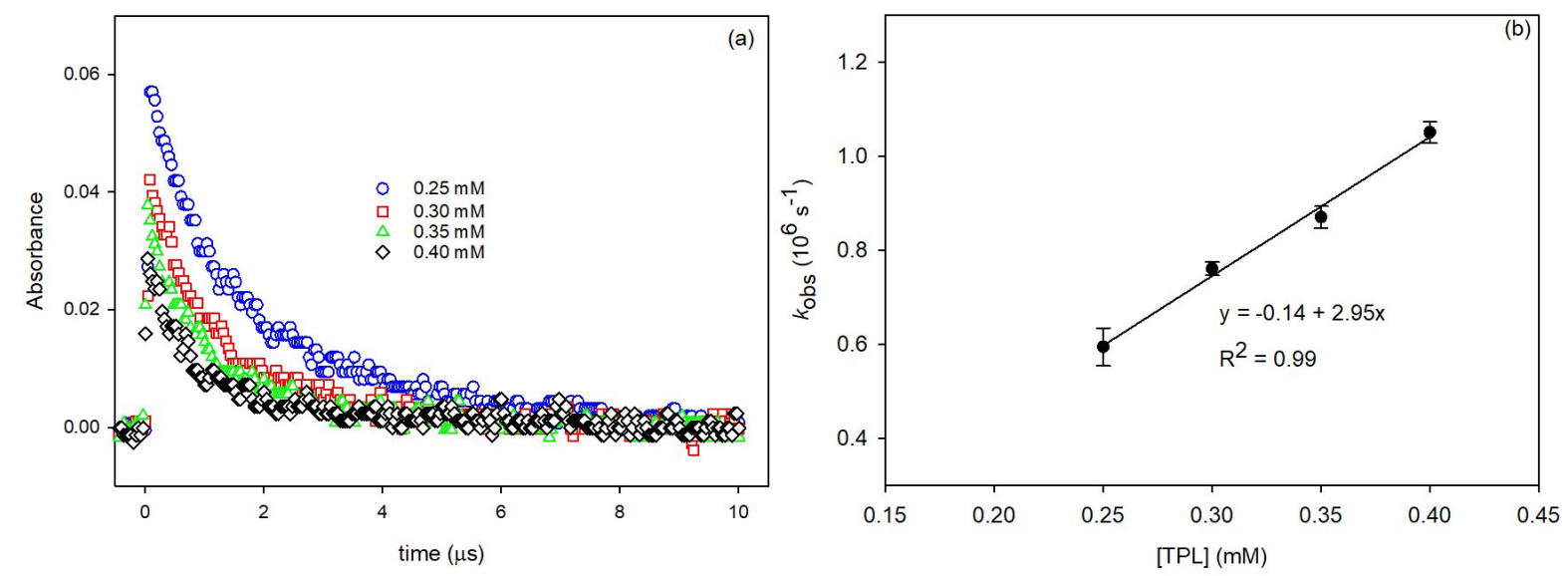

Figure S3. (a) Transient decay traces of $\mathrm{SO}_{4}{ }^{\circ-}$ at $450 \mathrm{~nm}$ with different concentrations of TPL.

(b) First-order decay rate constant $k_{\mathrm{obs}}$ vs. [TPL].
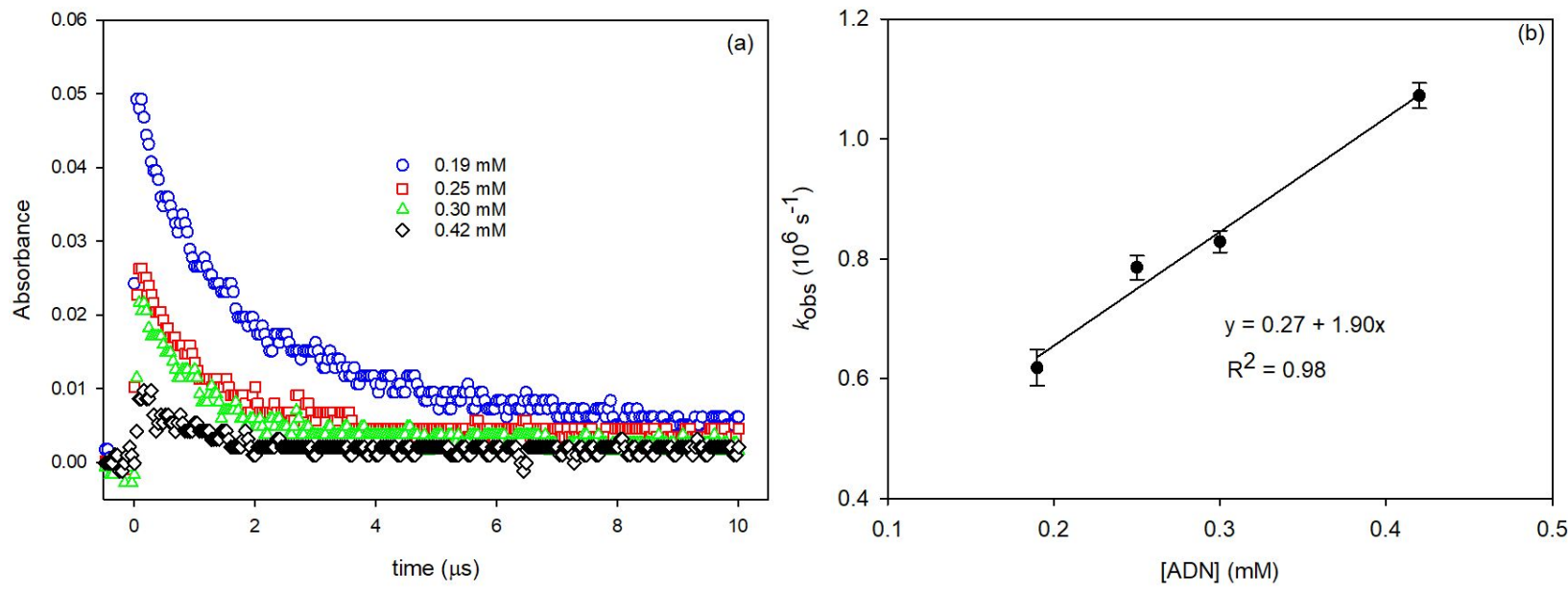

Figure S4. (a) Transient decay traces of $\mathrm{SO}_{4}{ }^{--}$at $450 \mathrm{~nm}$ with different concentrations of ADN. (b) First-order decay rate constant $k_{\text {obs }}$ vs. [ADN]. 

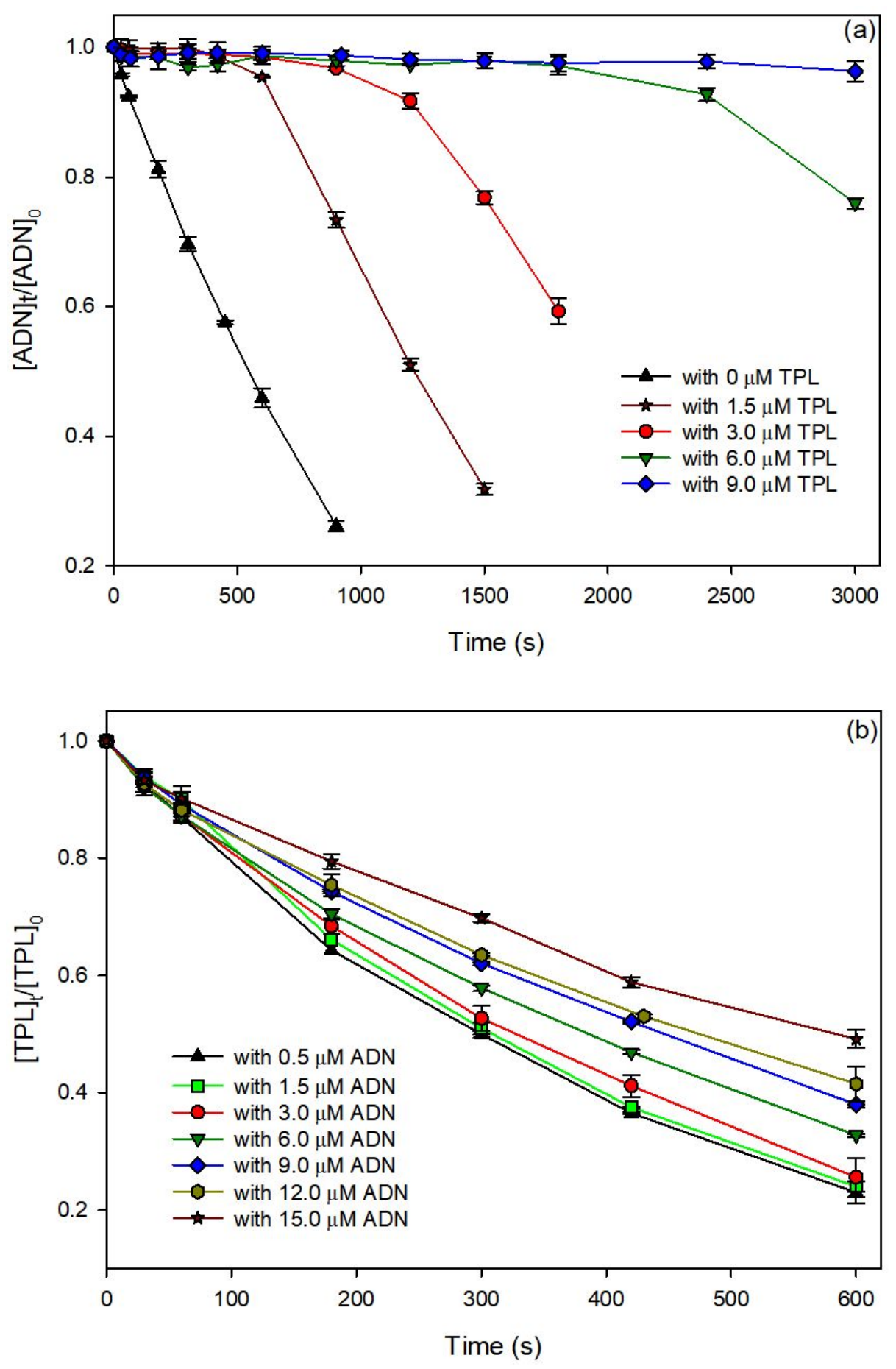

Figure S5. The degradation of (a) ADN and (b) TPL during UV/PDS treatment in single-component system $\left(3.0 \mu \mathrm{M}\right.$ TPL or $3.0 \mu \mathrm{M}$ ADN) or mixture systems. Conditions: $\mathrm{I}_{0}=$ $0.16 \mathrm{~mW} / \mathrm{cm}^{2}, \mathrm{pH}=7.0,\left[\mathrm{~K}_{2} \mathrm{~S}_{2} \mathrm{O}_{8}\right]=290 \mu \mathrm{M}$. 


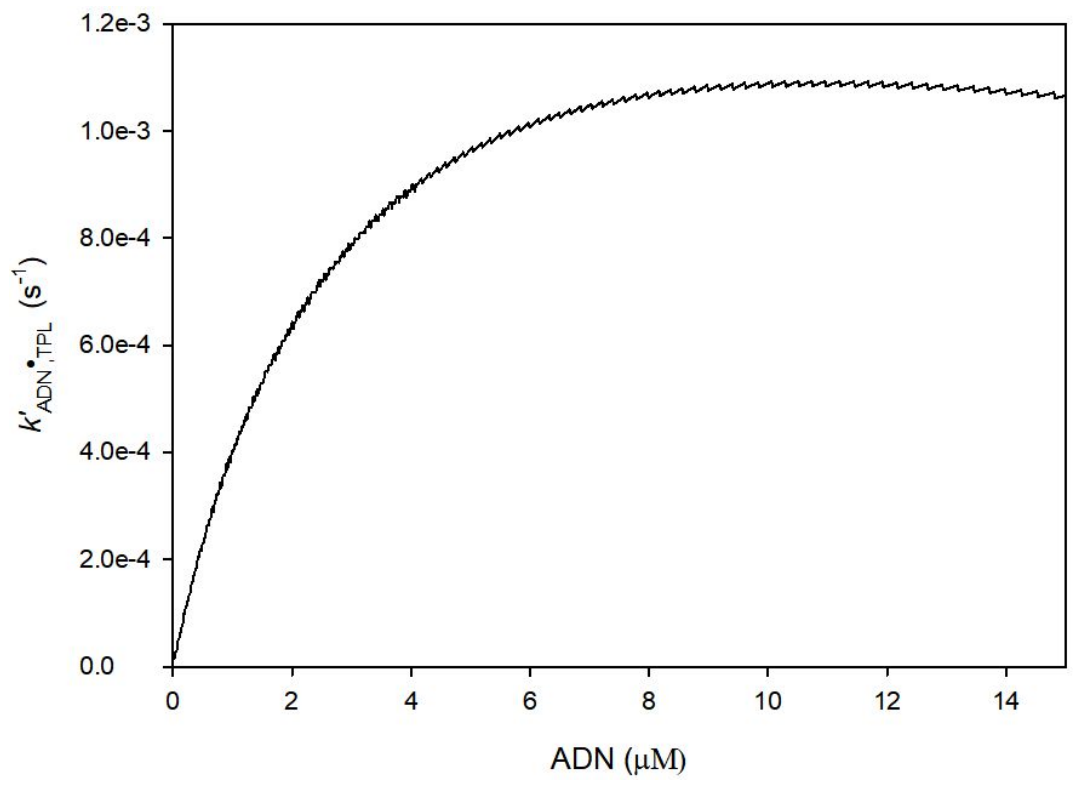

Figure S6. The predicted TPL degradation rate constant $k_{\mathrm{ADN}(-\mathrm{H}) \bullet, T P L}^{\prime}$ during UV/PDS treatment at various $\mathrm{ADN}$ concentrations.

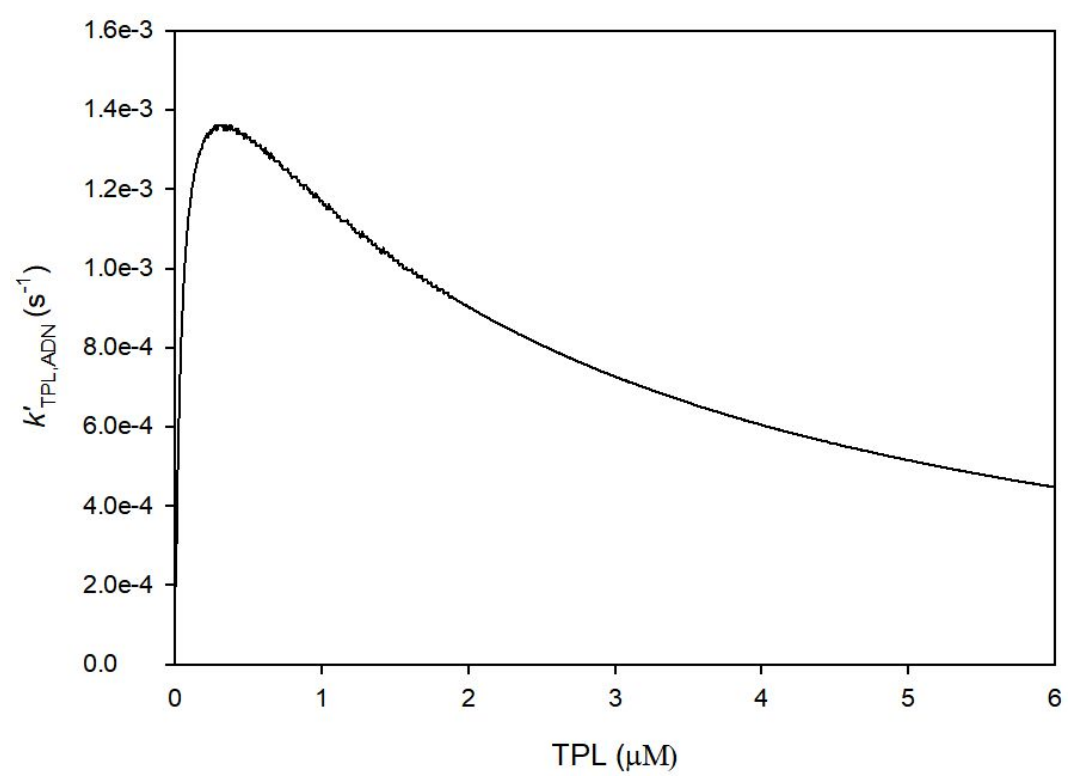

Figure S7. The predicted ADN degradation rate constant $k_{\text {TPL,ADN }}^{\prime}$ during UV/PDS treatment at various TPL concentrations. 
(a)

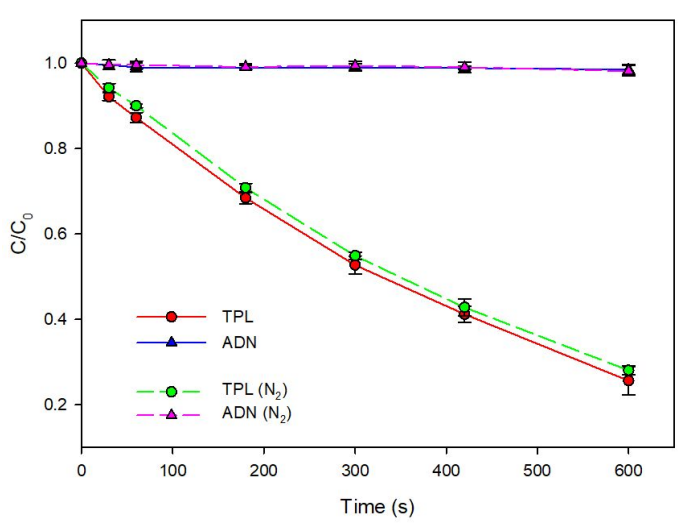

(b)

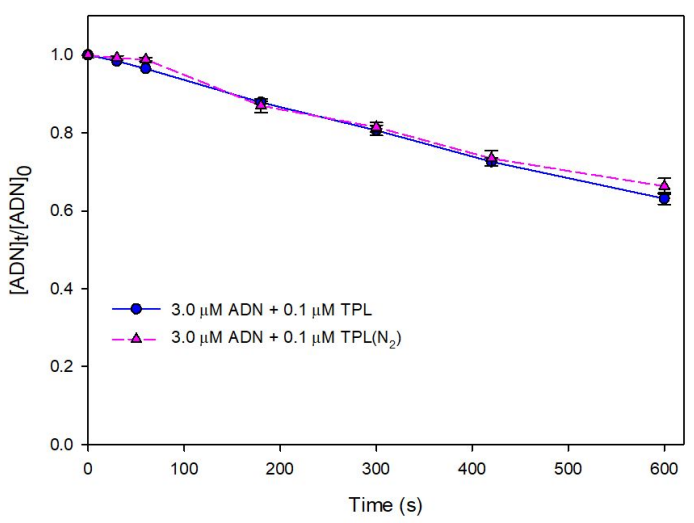

Figure S8. (a)The degradation of TPL and ADN in mixture system $(3.0 \mu \mathrm{M}$ TPL and $3.0 \mu \mathrm{M}$ $\mathrm{ADN})$ and (b) the degradation of $\mathrm{ADN}$ in mixture system $(0.1 \mu \mathrm{M}$ TPL and $3.0 \mu \mathrm{M}$ ADN) without $\mathrm{N}_{2}$ purging (solid line) and with $\mathrm{N}_{2}$ purging (dash line) during UV/PDS treatment. Conditions: $\mathrm{I}_{0}=0.16 \mathrm{~mW} / \mathrm{cm}^{2}, \mathrm{pH}=7.0,\left[\mathrm{~K}_{2} \mathrm{~S}_{2} \mathrm{O}_{8}\right]=290 \mu \mathrm{M}$.

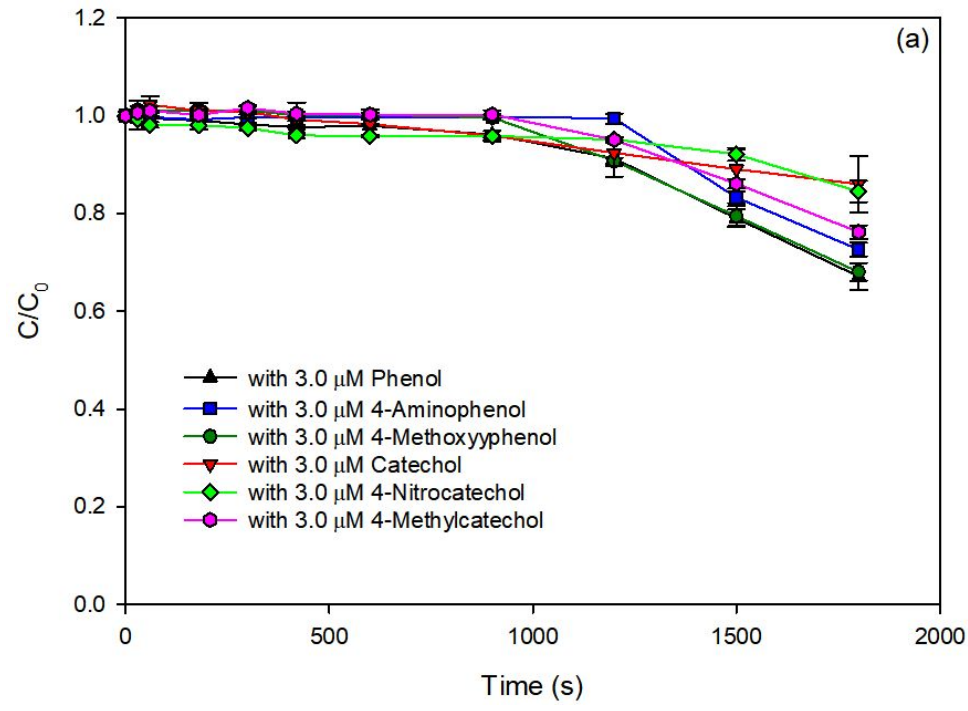



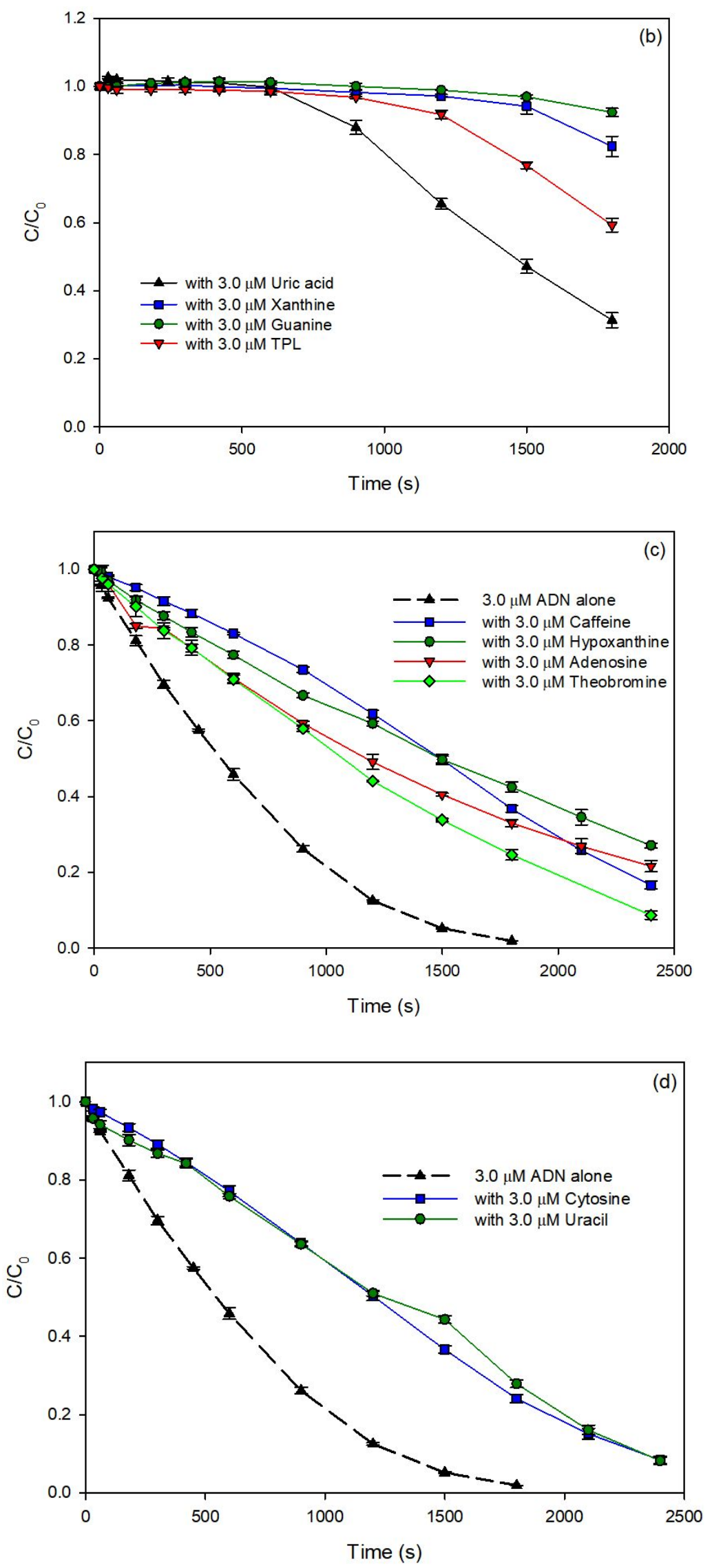
Figure S9. The degradation of $3.0 \mu \mathrm{M}$ ADN during UV/PDS treatment in mixtures containing $3.0 \mu \mathrm{M}$ (a) phenols, (b) purines with low reduction potential ( $<1.32 \mathrm{~V}$ vs SHE), (c) purines with high redox potential $\left(>1.32 \mathrm{~V}\right.$ vs SHE), (d) pyrimidines. Conditions: $\mathrm{I}_{0}=0.16$ $\mathrm{mW} / \mathrm{cm}^{2}, \mathrm{pH}=7.0,\left[\mathrm{~K}_{2} \mathrm{~S}_{2} \mathrm{O}_{8}\right]=290 \mu \mathrm{M}$.

(a)

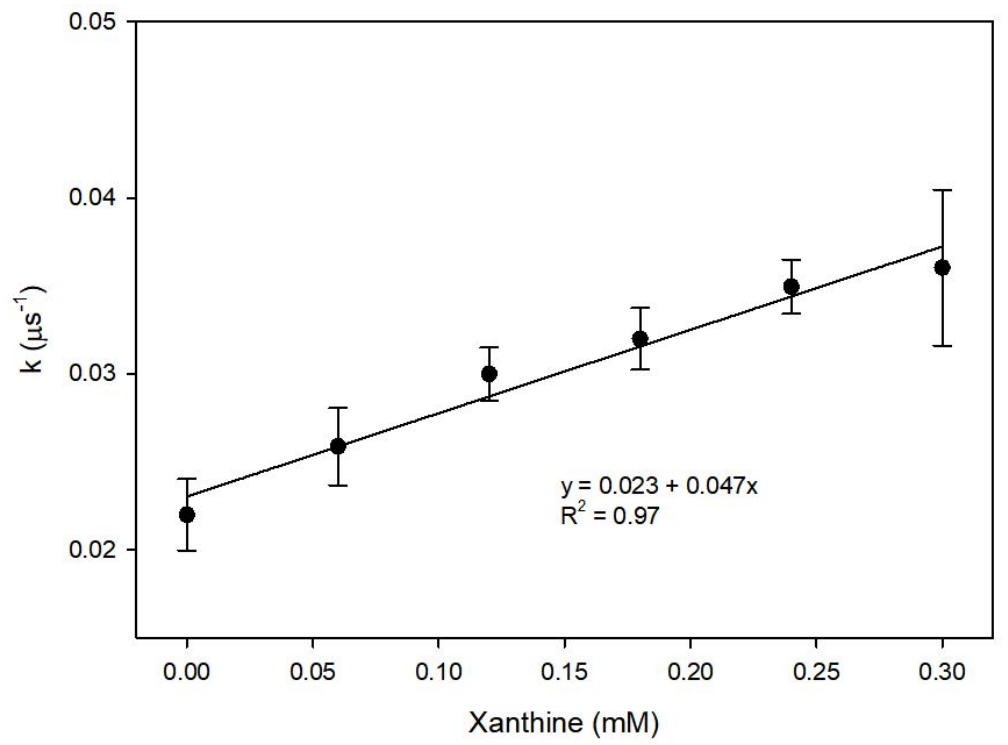

(b)

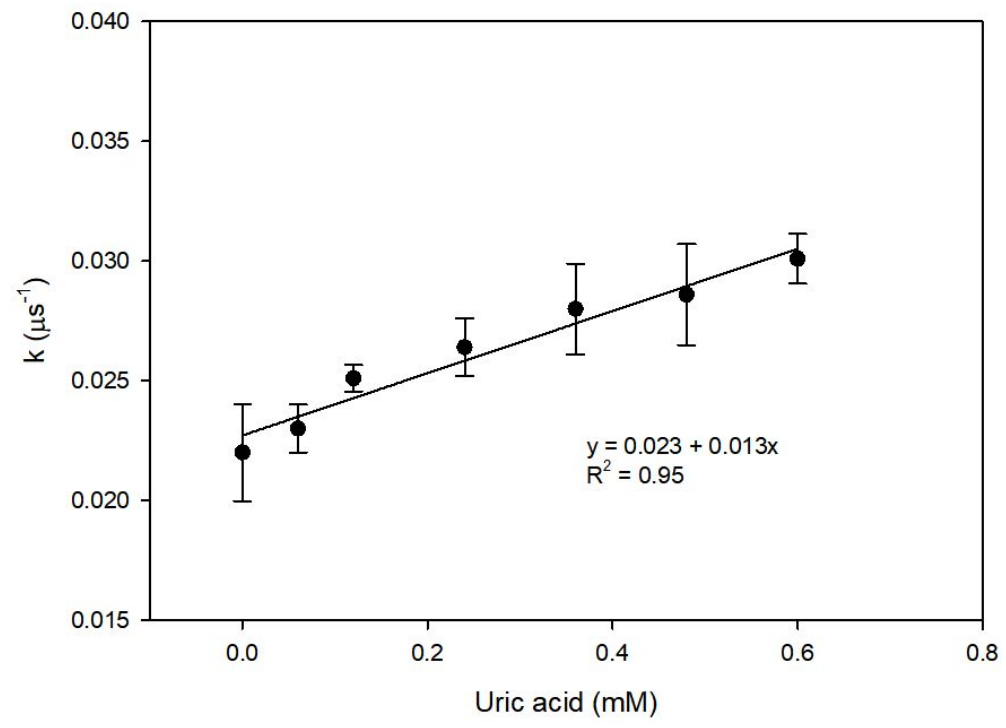


(c)

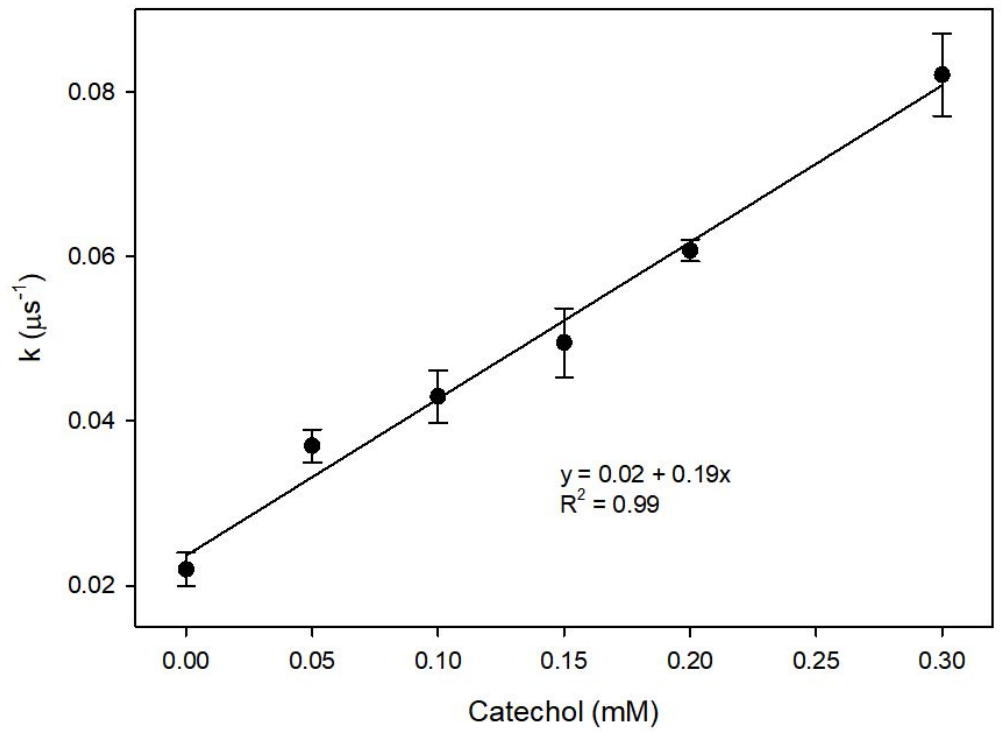

Figure S10. First-order decay rate constants of $\mathrm{ADN}(-\mathrm{H})^{\bullet}$ at various concentrations of (a) xanthine; (b) uric acid; (c) catechol. 

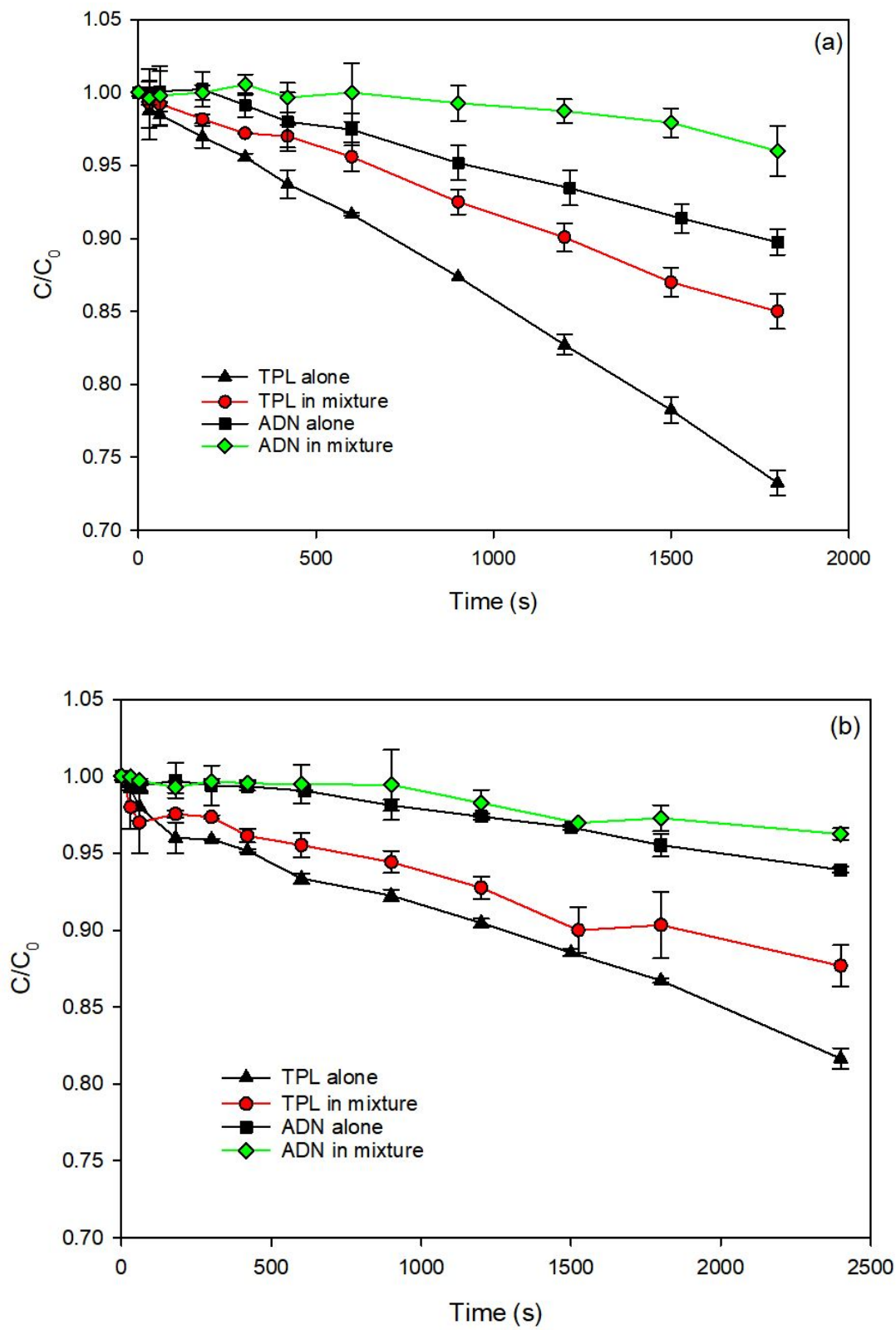

Figure S11. The degradation of TPL and ADN during UV/PDS treatment in single-component system and in mixture systems in (a) a simulated natural water containing Suwannee River NOM isolate (Cat. No. 2R101N, International Humic Substances Society) $2.5 \mathrm{mgC} \mathrm{L}^{-1}$ as DOC; (b) a real surface water. 


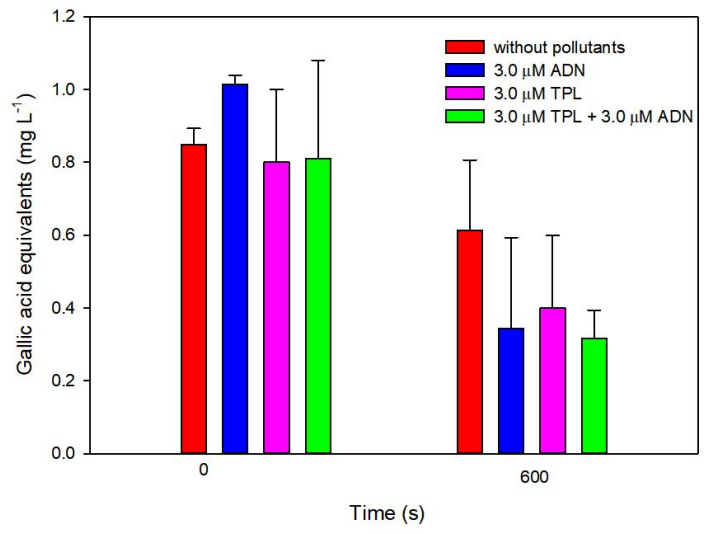

Figure S12. The total antioxidant capacity of NOM in the absence and presence of pollutants after 10 min during UV/PDS treatment. Conditions: $\mathrm{I}_{0}=0.16 \mathrm{~mW} / \mathrm{cm}^{2}, \mathrm{pH}=7.0,\left[\mathrm{~K}_{2} \mathrm{~S}_{2} \mathrm{O}_{8}\right]=$ $290 \mu \mathrm{M},[\mathrm{NOM}]=2.5 \mathrm{mgC} \mathrm{L}^{-1}$ as DOC. 


\section{REFERENCES}

(1) Ainsworth, E. A.; Gillespie, K. M. Estimation of total phenolic content and other oxidation substrates in plant tissues using Folin-Ciocalteu reagent. Nature protocols 2007, 2 (4), 875-877.

(2) Huang, D. J.; Ou, B. X.; Prior, R. L. The chemistry behind antioxidant capacity assays. J. Agric. Food. Chem. 2005, 53 (6), 1841-1856.

(3) Gan, W.; Huang, S.; Ge, Y.; Bond, T.; Westerhoff, P.; Zhai, J.; Yang, X. Chlorite formation during $\mathrm{ClO}_{2}$ oxidation of model compounds having various functional groups and humic substances. Water Res. 2019, 159, 348-357.

(4) Vieira, A. J. S. C.; Steenken, S. Pattern of $\mathrm{OH}$ radical reaction with adenine and its nucleosides and nucleotides. Characterization of two types of isomeric $\mathrm{OH}$ adduct and their unimolecular transformation reactions. J. Am. Chem. Soc. 1990, 112 (19), 6986-6994.

(5) Paul, M. M. S.; Aravind, U. K.; Pramod, G.; Saha, A.; Aravindakumar, C. T. Hydroxyl radical induced oxidation of theophylline in water: A kinetic and mechanistic study. Org. Biomol. Chem. 2014, 12 (30), 5611-5620.

(6) Faraggi, M.; Broitman, F.; Trent, J. B.; Klapper, M. H. One-electron oxidation reactions of some purine and pyrimidine bases in aqueous solutions. Electrochemical and pulse radiolysis studies. J. Phys. Chem. 1996, 100 (35), 14751-14761.

(7) Spataru, N.; Sarada, B. V.; Tryk, D. A.; Fujishima, A. Anodic voltammetry of xanthine, theophylline, theobromine and caffeine at conductive diamond electrodes and its analytical application. Electroanalysis 2002, 14 (11), 721-728.

(8) Ross, A. B.; Bielski, B. H. J.; Buxton, G. V.; Cabelli, D. C.; Helman, W. P.; Huie, R. E.; Grodkowski, J.; Neta, P.; Mulazzani, Q. G.; Wilkinson, F. NIST Standard Reference Database 40: NDRL/NIST Solutions Kinetics Database V 3.0,. Gaithersburg, MD. 1988.

(9) Yang, Y.; Pignatello, J. J.; Ma, J.; Mitch, W. A. Comparison of halide impacts on the efficiency of contaminant degradation by sulfate and hydroxyl radical-based advanced oxidation processes (AOPs). Environ. Sci. Technol. 2014, 48 (4), 2344-2351.

(10) Vieira, A. J. S. C.; Telo, J. P.; Pereira, H. F.; Patrocínio, P. F.; Dias, R. M. B. 
Antioxidant effect of naturally occurring xanthines on the oxidative damage of DNA bases. $J$. Chim. Phys. 1999, 96 (1), 116-123.

(11) Steenken, S.; Jovanovic, S. V. How easily oxidizable is DNA? One-Electron reduction potentials of adenosine and guanosine radicals in aqueous solution. J. Am. Chem. Soc. 1997, $119(3), 617-618$.

(12) Zhang, F. Y.; Wang, Z. H.; Zhang, Y. Z.; Zheng, Z. X.; Wang, C. M.; Du, Y. L.; Ye, W. C. Simultaneous electrochemical determination of uric acid, xanthine and hypoxanthine based on poly(L-arginine)/graphene composite film modified electrode. Talanta 2012, 93, $320-325$.

(13) Pavitt, A. S.; Bylaska, E. J.; Tratnyek, P. G. Oxidation potentials of phenols and anilines: correlation analysis of electrochemical and theoretical values. Environ. Sci.: Processes Impacts 2017, 19 (3), 339-349.

(14) Salgado, P.; Melin, V.; Duran, Y.; Mansilla, H.; Contreras, D. The reactivity and reaction pathway of fenton reactions driven by substituted 1,2-dihydroxybenzenes. Environ. Sci. Technol. 2017, 51 (7), 3687-3693. 